\title{
Descemet Membrane Endothelial Keratoplasty Combined with Phacoemulsification and Intraocular Lens Implantation
}

\author{
[ ] Seyhan Kocabaş, (1) Baran Kandemir
}

Department of Ophthalmology, University of Health Sciences, Kartal

Dr. Lütfi Kırdar Training and Research Hospital, İstanbul, Turkey

Submitted: 26.05 .2020 Accepted: 28.09.2020

Correspondence: Seyhan Kocabaş, SBÜ Kartal Dr. Lütfi Kırdar Eğitim ve Araştırma Hastanesi, Göz Hastalıkları Kliniği, İstanbul, Turkey

E-mail: seyhankcbs@gmail.com

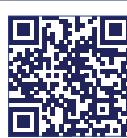

Keywords: Combined modality treatment; cornea transplantation; Fuchs' endothelial dystrophia.

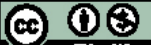

This workis licensed underacreave Com This work is licensed under a Creative Commons
Attribution-NonCommercial 4.0 International License.

\begin{abstract}
Objective: This study aims to assess visual anatomic outcomes and complications of Descemet Membrane Endothelial Keratoplasty (DMEK) combined with phacoemulsification and intraocular lens implantation in patients with coexisting endothelial dysfunction and cataract.
\end{abstract}

Methods: Triple DMEK (DMEK with simultaneous cataract surgery) was performed in 39 eyes of the 32 patients. Best-corrected Visual Acuity (BCVA), Endothelial Cell Density (ECD), Central Corneal Thickness (CCT), Refractive Spherical Equivalent (RSE), air injections (Re-bubbling) frequency and complications were assessed preoperatively and postoperative months I, 3, 6 and I 2 .

Results: BCVA increased from $1.22 \pm 0.32$ logMAR preoperatively to $0.19 \pm 0.18(n=33)$ and $0.11 \pm 0.09(n=27)$ at six months and 12 months after surgery, respectively $(p<0.05$; Wilcoxon test). The mean ECD of donor corneas decreased from $277 \mathrm{I} \pm 284 \mathrm{cell} / \mathrm{mm}^{2}(\mathrm{n}=39)$ to $140 I \pm 270 \mathrm{cell} / \mathrm{mm}^{2}(\mathrm{n}=32)$ after six months and to $1373 \pm 217 \mathrm{cell} / \mathrm{mm}^{2}(\mathrm{n}=24)$ after 12 months $(p<0.05)$. Preoperative CCT decreased from $696 \pm 99 \mu \mathrm{m}$ and to $518 \pm 42 \mu \mathrm{m}$ and $517 \pm 35 \mu \mathrm{m} 6$ and 12 months after surgery, respectively $(p<0.05)$. The mean RSE was $-0.57 \pm 0.69 D(n=21)$ preoperatively and $+0.47 \pm 0.65 D(n=3 I)$ and $0.48 \pm 0.67 D(n=27) 6$ and 12 months after surgery. The mean RSE was detected $\leq$ ID in $82 \%$ of the patients at $12^{\text {th }}$ month. Re-bubbling was performed once in seven eyes (17.9\%) and twice in two eyes (5.12\%). Re-DMEK was performed in six of seven eyes of which graft failure developed, whereas penetrating keratoplasty was performed in one eye.

Conclusion: Triple DMEK may consistently give predictable refractive results without adverse endothelial function. Hence, triple DMEK can be considered as the primary treatment approach in cases with endothelial dysfunction and cataract.

\section{INTRODUCTION}

Descemet membrane endothelial keratoplasty (DMEK) is defined by Melles ${ }^{[1]}$ in 2006 and is usually preferred in the eyes with endothelial dysfunction due to low rejection reaction risk, rapid visual rehabilitation, lack of suture complications and advantages of closed system surgery. ${ }^{[2-6]}$

Pseudophakic bullous keratopathy and Fuchs' endothelial dystrophy are major indications for penetrating keratoplasty due to endothelial dysfunction. ${ }^{[7,8]}$ Fuchs' endothelial dystrophy is frequently concomitant to cataract at the time of penetrating keratoplasty. ${ }^{\left[{ }^{[9]}\right.}$ Cataract surgery may be performed before, during or after keratoplasty. ${ }^{[10]}$ Since the change in corneal curvature is less after DMEK, predictability of postoperative refraction levels increase. Therefore, the attention on combined cataract surgery has increased in the patients with Fuchs' endothelial dystrophy. ${ }^{\left[{ }^{11}\right]}$

This study aims to assess the results of triple-DMEK, including Best-corrected Visual Acuity (BCVA), Endothelial Cell Density (ECD), Central Corneal Thickness (CCT), mean Refractive Spherical Equivalent, air injections (re-bubbling) (Rb) frequency and complications rates within follow up of 12 months.

\section{MATERIALS AND METHODS}

The present study was approved by the Kartal Dr. Lütfi Kırdar City Hospital Ethics Committee on April 28, 2017 (no: 2017/5/4/106/6). Thirty-nine eyes of 32 patients who were exposed to Triple DMEK procedure between January 
2014 and July 2018 were enrolled in this study. Data of the aforementioned patients were evaluated retrospectively.

\section{Study protocol}

Anterior and posterior segment examinations, BCVA, autorefractometer values, central $3 \mathrm{~mm} \mathrm{KI}$ and $\mathrm{K} 2$ measures in corneal topography (Sirius corneal topography, Costruzione Strumenti Oftalmici, Florence, Italy), ECD (Topcon specular microscope, Tokyo, Japan) and CCT (Optikon Pacline, Rome, Italy) values of the patients recorded into this study during the preoperative and the postoperative follow-ups. Indications for Triple DMEK were Fuchs' endothelial dystrophy $(n=37)$ and bullous keratopathy secondary to phakic GIL $(n=2)$. This study was approved by the institutional review board and conducted in compliance with the Helsinki declaration.

\section{Intraocular lens calculation}

The keratometry measurements obtained by IOL Master (V.4.08; Carl Zeiss Meditec, Jena, Germany) and corneal topography keratometry measurements were compared; and the measurements to be used for the calculation of lens strength were detected. Axial length was calculated by A-scan (E-Z Scan 5500, New York, USA) for the cases whose measurements could not be obtained by the IOL Master device due to corneal opacification. Since axial lengths of all patients were between 22 and $25 \mathrm{~mm}$, the SRK-T formula was used in IOL Master to calculate GIL strength. Refraction value was planned as $-0.50 \mathrm{D}$.

\section{Surgical technique}

Modified Van Lint facial block and retrobulbar anaesthesia ( $2 \%$ lidocaine hydrochloride and $0.5 \%$ bupivacaine hydrochloride) were applied to all patients. Intraocular pressure (IOP) was reduced by ocular massage and/or Honan balloon following local anaesthesia. The corneal epithelium was peeled off to clear the vision when it deemed necessary in some cases following routine surgical preparations. After standard phacoemulsification surgery and intraocular lens (IOL) implantation, endothelial was marked to determine the descematorhexis margin. Descematorhexis of $\mathbf{8 . 5}$ $\mathrm{mm}$ was performed under a viscoelastic substance (sodium hyaluronate, Bio-hyalur EV, Biotech, India). The viscoelastic substance behind the anterior chamber and IOL and Descemet membrane residues were cleared through irrigation and aspiration. Myosis was created by the application of carbachol (Miostat Single, Novartis Pharma GmbH, Germany) onto the anterior chamber. Peripheral iridectomy was performed at 6 o'clock level through a 23 G vitrectomy probe.

The cornea was placed on a vacuum block (Barron; Katenaproducts, inc. USA) while the donor Descemet-endothelium complex was prepared. The Descemet membrane was marked by $Y$ spatula or a $9.5 \mathrm{~mm}$ punch trepan. The marked area was made visible by staining with $0.06 \%$ trypan blue (Ocublu-Try; Bursa, Turkey). The Descemet-endothelium complex was separated more than $50 \%$ by forceps. After the partially separated graft lied again, the donor endothelium peeling procedure was completed through forceps by incising $3 \mathrm{~mm}$ in diameter at least (7-8-8.25 mm) with a trepan.

The descemet-endothelium complex preparate was stained by $0.06 \%$ trypan blue; then, a standard lens cartridge (Zaraccom cartridge and injection system; Sivas, Turkey) was implanted onto the anterior chamber. The graft was centralized by fluid flushing laterally and manipulations were performed to the anterior side of the cornea; and the endothelium surface facing the iris was opened. A contact was provided between the graft and stroma through air inflation into the anterior chamber. The surgical procedure was terminated by suturing the cornea orifices following the injection of subconjunctival gentamycin (Gentamicin, Deva) and dexamethasone (Dekort, Deva). The patients were advised to lie in a supine position to achieve graft adhesion onto the stroma during the postoperative period.

\section{Postoperative follow-up}

Moxifloxacin hydrochloride $0.5 \%$ (Vigamox, Alcon) and dexamethasone $0.1 \%$ (Maxidex, Alcon) were prescribed to be used five times a day for all eyes after the surgery. Autologous serum infusion was started five times a day for the patients whose epitheliums were peeled until the epithelial recovery is achieved. Corneal sutures were removed within 15 days after the surgery. Autologous serum treatment was discontinued after corneal epithelization. Topical antibiotic therapy was also discontinued in all cases on a postoperative day 10. The dexamethasone was replaced with loteprednol etabonate $0.5 \%$ at the end of the third month, which was gradually tapered and discontinued. Postoperative IOP increase was defined as $22 \mathrm{mmHg}$ and over.

The patients whose corneal edema or graft detachment was detected by biomicroscopic examination were evaluated with optic coherence tomography (OCT) of the anterior segment; and the necessity of re-bubbling was considered. Re-bubbling was performed in the presence of peripheral detachment that prevents visual axis or presents large or roll formation within the first one month. The aforementioned procedure was performed by opening the graft again under local anaesthesia when necessary and advising the supine position to the patient after re-bubbling. Follow-up was deemed adequate in peripheral detachment cases which do not distort visual axis or present flat formation.

\section{Statistical Analysis}

PASW Statistics (SPSS) 18 was used for statistical analyses. Wilcoxon, Fisher exact and t-test were used for comparison. The statistical significance threshold was taken as $\mathrm{p}<0.05$.

\section{RESULTS}

Thirty-nine eyes of 32 patients ( 9 males, 23 females) who underwent Triple DMEK surgery were enrolled in the 
present study. The mean age of the Triple DMEK patients was 66.69 13.28 (range 24-94) years.

The average BCVA of the patients whom triple DMEK surgery was planned at LogMAR scale was I.22 \pm 0.32 $(n=39)$, whereas it was detected $0.65 \pm 0.38 \quad(n=39)$, $0.39 \pm 0.37(n=38), 0.18 \pm 0.18(n=33)$ and $0.11 \pm 0.09(n=27)$ at months I, 3, 6 and I2, respectively. The increase in BCVA was statistically significant in the first month $(p<0.05$; Wilcoxon test), between month I and month 3 ( $p<0.05$; Wilcoxon test), between $6^{\text {th }}-12^{\text {th }}$ months $(p<0.05$; Wilcoxon test) (Fig. I). The BCVA was 0.3 LogMAR or better in $15.3 \%$ of all eyes at Ith month; such rate increased to $57.8 \%(n=22)$ at postoperative $3^{\text {th }}$ month, $75.7 \%(n=25)$ at the $6^{\text {th }}$ month and $100 \%(n=27)$ at the $12^{\text {th }}$ month.

The average donor ECD of the patients in preoperative measurements was $277 \mathrm{I} \pm 284 \mathrm{cell} / \mathrm{mm}^{2}$, whereas it was measured as $1749 \pm 472(n=39), 1513 \pm 397 \quad(n=38)$, $1497 \pm 270 \quad(n=32)$ and $1473 \pm 217 \quad(n=24) \quad$ cell $/ \mathrm{mm}^{2}$ at months I, 3, 6 and I2, respectively. The decrease in ECD between $I^{\text {th }}-3^{\text {rd }}$ months was statistically significant $(p<0.05$; Wilcoxon test) whereas the difference in ECD at month 6

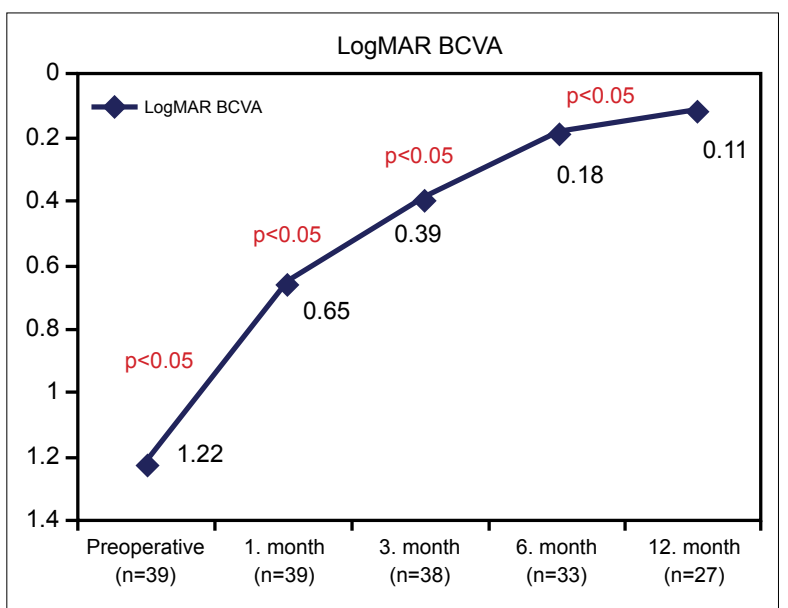

Figure 1. Best-corrected visual acuity values of the patients according to the months ( ${ }^{*}$ Wilcoxon test).

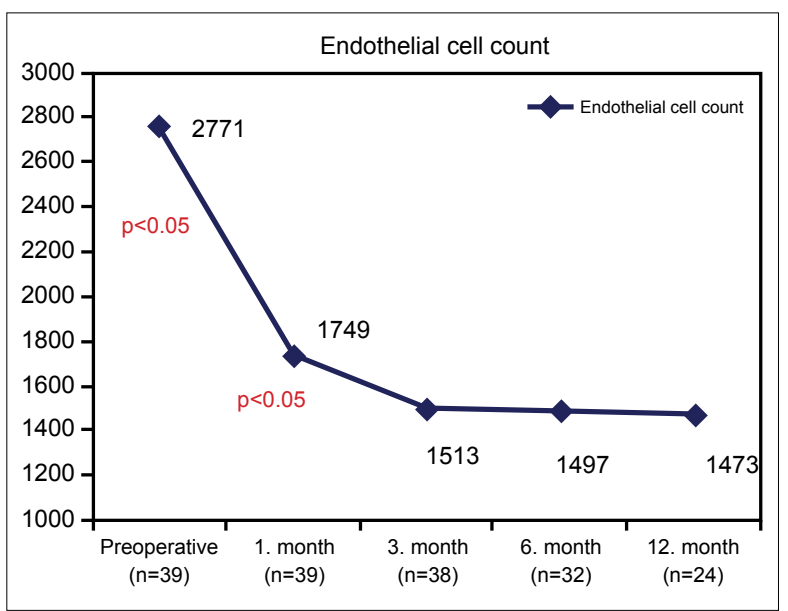

Figure 2. Endothelial cell count measurements according to the months ("Wilcoxon test). and between sixth and twelfth months was not statistically significant ( $p<0.05$; Wilcoxon test) (Fig. 2). The loss rates detected between preoperative donor ECD and postoperative ECD at months 3, 6 and 12 were $45.4 \%, 46 \%$ and $46.9 \%$, respectively.

The preoperative CCT average was $696 \pm 99 \mu \mathrm{m}(\mathrm{n}=39)$, whereas it was detected $593 \pm 65(n=39), 554 \pm 87(n=38)$, $518 \pm 42(n=33)$ and $517 \pm 35 \mu m(n=27)$ at months I, 3 , 6 and 12, respectively. The decrease in CCT in the first month, between first and third months and between third and sixth months were statistically significant $(p<0.05$; Wilcoxon test), whereas the difference in CCT between sixth and twelfth months was not statistically significant (Fig. 3).

The preoperative mean RSE was $-0.57 \pm 0.44 D(n=2 I)$, whereas it was measured as $+0.45 \pm 0.68$ D $(n=32)$, $+0.37 \pm 0.74 D(n=33),+0.47 \pm 0.74 D(n=32)$ and $+0.48 \pm 0.67$ D (=27) at months I, 3, 6 and I2, respectively. The mean RSE change between the preoperative period and the postoperative first month was statistically significant $(p<0.05$; Wilcoxon test); however, the difference in the measure-

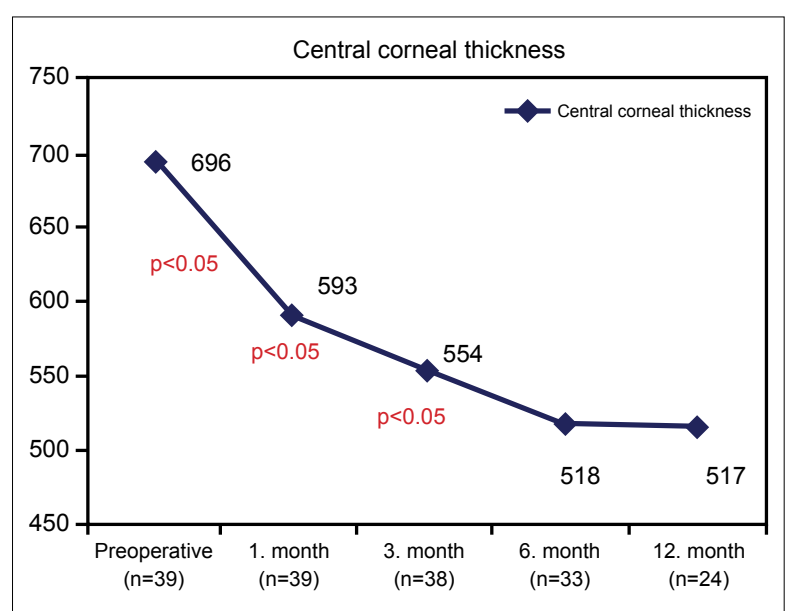

Figure 3. Central corneal thickness measurements according to the months (*Wilcoxon test).

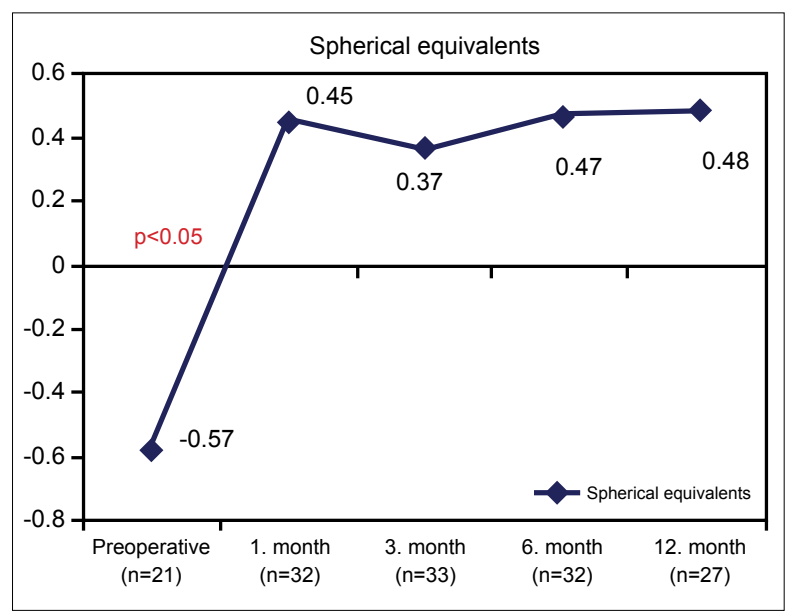

Figure 4. Spherical equivalent measurement values of the patients according to the months. 
ments obtained in other months was not statistically significant ( $p<0.05$; Wilcoxon test) (Fig. 4). Mean spherical equivalent was found at and below I D in $84 \%$ of the patients at the sixth month, whereas none of the patients presented mean spherical equivalent at and above 2 D. Mean spherical equivalent was found at and below I D in $82 \%$ of the patients at twelfth month, whereas none of the patients presented mean spherical equivalent at and above $2 \mathrm{D}$.

Re-bubbling procedure was performed once on seven eyes (I7.9\%) and twice on two eyes (5.12\%) among the cases enrolled in this study. Re-bubbling was not deemed necessary in $30(76.9 \%)$ patients.

Primary graft failure was decided on four (21.7\%) out of seven eyes at the end of the first month and three out of seven eyes at the end of the third month. Among the aforementioned patients, DMEK was repeated on six eyes, and penetrating keratoplasty was performed on one patient in the postoperative third month. There was not any complication detected in any of the patients who had recurrent DMEK during the follow-up period.

Intraocular pressure was not detected in any of the patients except two cases in our study group. IOP increase was controlled by the transition from potent active agent steroid regimen to low effect steroid therapy and topical antiglaucomatous therapy (a fixed combination of topical dorzolamide+timolol maleate $2 \times \mathrm{l}$ ). None of the patients developed rejection.

\section{DISCUSSION}

Lamellar surgical techniques where the corneal endothelial layer is replaced have been rapidly developed in recent years. Descemet Stripping Automated Endothelial Keratoplasty (DSAEK) and DMEK are two preferred endothelial keratoplasty techniques for the diseases with corneal endothelial dysfunction. The advantages of endothelial keratoplasty to penetrating keratoplasty are rapid visual rehabilitation, absence of suture complications, advantages of closed system surgery and decreased risk of graft rejection reaction. ${ }^{[1,11-14]}$

The factors limiting of DMEK surgery are challenges in donor preparation relatively, longer time about learning of surgical technique and higher early complication rates in initial cases during first years that the procedure was started to be used in an ophthalmology practice. ${ }^{[15]}$ The interest in DMEK surgery gradually increased since first use following continuous satisfying outcomes. American Eye Bank data reported that percentages of DMEK surgery in all keratoplasty procedures in the USA were $0.7 \%$ in $2011,1.6 \%$ in $2012,3.2 \%$ in $2013,6.0 \%$ in 2014 and $9.6 \%$ in $2016 .^{[16]}$

In our study, mean BCVA, according to the LogMAR scale, was detected 1.22 preoperatively, whereas it increased considerably from the first month. An increase at and above 7 averagely was detected at the end of twelfth month. Laaser et al. ${ }^{\left[{ }^{11]}\right.}$ reported similar outcomes in their study. Chaurasia et al. ${ }^{[17]}$ compared Triple DMEK $(n=200)$ and single DMEK $(n=292)$ cases and reported that the average BCVA was significantly higher at the end of postoperative sixth month with one rank better BCVA values was in that the Triple DMEK group. The authors reported that the average age in the Triple DMEK surgery group was lower and younger age and postoperative visual outcomes were correlated. ${ }^{[17]}$ Another explanation for one rank lower final visual acuity in the single DMEK compared to Triple DMEK may be a history of cataract surgery with complications in the single DMEK surgery.

Mean RSE was measured $+0.37 \pm 0.74 \mathrm{D}(\mathrm{n}=33)$ at postoperative $3^{\text {th }}$ month $+0.47 \pm 0.74 D(n=32)$ at postoperative $6^{\text {th }}$ month and $+0.48 \pm 0.67 \mathrm{D}(\mathrm{n}=27)$ at postoperative $12^{\text {th }}$ month. Refractive Spherical Equivalent, was found I D in $84 \%$ of the patients at postoperative $6^{\text {th }}$ month whereas none of the patients presented RSE at and $\geq 2 \mathrm{D}$. RSE was found at and $\leq I D$ in $82 \%$ of the patients at twelfth month, whereas none of the patients presented RSE at and above 2 D. These data are similar with the outcomes on Triple DSAEK and Triple DMEK published yet. ${ }^{[10,11,18]}$

In the recent literature on outcomes of DMEK and Triple DMEK surgery, the existence of hyperopic sliding caused us to select a target refraction of $-0.50 .^{[19-21]}$ However, our postoperative hyperopic shift range between +0.50 and $+0.75 \mathrm{D}$ showed that we should review our refraction target selections of IOL for emmetropization. We believe that the change of target refraction as $-0.75 \mathrm{D}$ for the selection of IOL would approximate us to emmetropization one step more in further cases.

The use of viscoelastic substances at the descemetorhexis stage in triple DMEK surgery is contradictory. Melles et al. suggested that the existence of viscoelastic substances on the anterior chamber may be a risk factor for dislocation of the graft, whereas Chaurasia et al. ${ }^{[17]}$ compared single DMEK to Triple DMEK surgery and could not find a significant difference between re-bubbling rates due to detachment of the graft. Laaser et al. ${ }^{\left[{ }^{\prime \prime}\right]}$ found that re-bubbling rates due to detachment of graft using viscoelastic substance at the descemetorhexis stage are similar to re-bubbling rates detected in the cases exposed to single DMEK in their study where outcomes of Triple DMEK cases were published. Re-bubbling procedure is performed once on seven eyes (17.9\%) and twice on two eyes (5.12\%) among the cases enrolled in the present study. Changes and developments in the surgical techniques revealed implantation of Descemet endothelial complex onto the anterior chamber following complete clearance of viscoelastic substances from the anterior chamber after the Descemetorhexis stage reduced such rates.

Another contradictory issue about Triple DMEK is the stability of IOL during the procedure. The cause of the contradiction is the risk of cell loss by contact of $\mathrm{IOL}$ with endothelium. The decrease in ESS was statistically significant between the preoperative first month and the postoperative first and third months, whereas the changes at the end of months 6 and 12 were not significant. The 
loss rates detected between preoperative donor ECD and postoperative ECD at months 3, 6 and I 2 were $45.4 \%, 46 \%$ and $46.9 \%$, respectively. The ECD loss reported in Triple DMEK studies varies between $19 \%$ and $40 \% .^{[5,6,11,17,22]}$ The reason for a slightly increased ECD loss when compared with the literature may be the development stage of our surgical experience. We believe that such rates would decrease by the increase in our experience.

Corneal thickness decrease and corneal transparency as well as a significant increase in visual acuity are detected within the first weeks after a successful surgical procedure. Recurrent DMEK procedure was performed in six of seven patients whose corneal edema did not regress or showed a significant recovery at the end of the second month. We believe that possible cause of graft failure was reverse opening of the grafts or endothelial injury during the surgery because of cornea transparency and consideration of a successful procedure on the eyes exposed to recurrent DMEK. The graft failures reported in the recurrent DMEK cases are mostly caused by intraoperative graft trauma, surgical experience and malposition of the graft. ${ }^{[23-25]}$

Primary graft failure after DMEK was reported between $0 \%$ and $9 \%$ whereas immunological graft failure was between $1 \%$ and $3 \%{ }^{[25,26]}$ There was not any significant difference between graft rejection rates after Triple DMEK and single DMEK procedures. ${ }^{[17]}$ Allograft rejection was not observed in any of the cases of the present study. The cause for the absence of rejection may be explained by a lower number of cases in our study group.

The cause for lower IOP increase after DMEK when compared with other keratoplasty techniques may be explained with visual and anatomic recovery at the end of the postoperative $3^{\text {rd }}$ month, lower rejection incidence when compared with other keratoplasty techniques and replacement of potent steroid regimen with low effect steroid regimens at $3^{\text {th }}$ month after DMEK. We reported the postoperative IOP to increase in two $(5.12 \%)$ cases that were controlled with medical treatment. Maier et al. ${ }^{[27]}$ reported IOP increase incidence as $12.1 \%$ and glaucoma rate as $2.7 \%$ after DMEK.

One of the limitations of the present study is the lack of a control group. The Triple DSAEK surgery, which may be evaluated as control group is not performed in our clinic. Another limitation of the present study is the limited number of patients and follow-up periods.

\section{CONCLUSION}

In conclusion, we believe that we obtained satisfying results on the eyes exposed to Triple DMEK surgery. Triple DMEK has some advantages, such as rapid visual rehabilitation, predictable refractive outcomes and lower complication risks; it has the potential to be the first treatment option for cases with corneal endothelial dysfunction and cataract.

Ethics Committee Approval

The study was approved by the Kartal Dr. Lütfi Kırdar
City Hospital Ethics Committee (date: 28.04.2017, no: 2017/514/106/6).

Informed Consent

Retrospective study.

Peer-review

Internally peer-reviewed.

Authorship Contributions

Concept: S.K., B.K.; Design: S.K., B.K.; Supervision: S.K., B.K.; Fundings: S.K., B.K.; Materials: S.K., B.K.; Data: S.K., B.K.; Analysis: S.K., B.K.; Literature search: S.K., B.K.; Writing: S.K., B.K.; Critical revision: S.K., B.K.

Conflict of Interest

None declared.

\section{REFERENCES}

1. Melles GR, San Ong T, Ververs B, van der Wees J. Descemet membrane endothelial keratoplasty (DMEK). Cornea 2006;25:987-90.

2. Anshu A, Price MO, Price FW. Risk of corneal transplant rejection significantly reduced with Descemet's membrane endothelial keratoplasty. Ophthalmology 2012;119:536-40. [CrossRef]

3. Guerra FP, Anshu A, Price MO, Giebel AW, Price FW. Descemet's membrane endothelial keratoplasty: prospective study of 1 -year visual outcomes, graft survival, and endothelial cell loss. Ophthalmology 2011;118:2368-73. [CrossRef]

4. Van Dijk K, Ham L, Tse WHW, Liarakos VS, Quilendrino R, Yeh R-Y, et al. Near complete visual recovery and refractive stability in modern corneal transplantation: Descemet membrane endothelial keratoplasty (DMEK). Cont Lens Anterior Eye 2013;36:13-21. [CrossRef]

5. Price MO, Giebel AW, Fairchild KM, Price FW. Descemet's membrane endothelial keratoplasty: prospective multicenter study of visual and refractive outcomes and endothelial survival. Ophthalmology 2009;116:2361-8. [CrossRef]

6. Ham L, Dapena I, Van Luijk C, Van der Wees J, Melles G. Descemet membrane endothelial keratoplasty (DMEK) for Fuchs endothelial dystrophy: review of the first 50 consecutive cases. Eye 2009;23:1990-8. [CrossRef]

7. Cengiz O, Cengiz MK, Erçalık NY, Eskiçırak B, Acar BT, Acar S. Penetran keratoplasti endikasyonları, 7 yıllık periyot. Glo-Kat 2012;7:153-8.

8. Dobbins KR, Price Jr FW, Whitson WE. Trends in the indications for penetrating keratoplasty in the midwestern United States. Cornea 2000;19:813-6. [CrossRef]

9. Terry MA, Shamie N, Chen ES, Phillips PM, Shah AK, Hoar KL, et al. Endothelial keratoplasty for Fuchs' dystrophy with cataract: complications and clinical results with the new triple procedure. Ophthalmology 2009;116:631-9. [CrossRef]

10. Covert DJ, Koenig SB. New triple procedure: Descemet's stripping and automated endothelial keratoplasty combined with phacoemulsification and intraocular lens implantation. Ophthalmology 2007;114:1272-7. [CrossRef]

11. Laaser K, Bachmann BO, Horn FK, Cursiefen C, Kruse FE. Descemet membrane endothelial keratoplasty combined with phacoemulsification and intraocular lens implantation: advanced triple procedure. Am J Ophthalmol 2012;154:47-55. [CrossRef]

12. Dapena I, Ham L, Melles GR. Endothelial keratoplasty: DSEK/ DSAEK or DMEK-the thinner the better? Curr Opin Ophthalmol 2009;20:299-307. [CrossRef]

13. Melles GR, San Ong T, Ververs B, Van der Wees J. Preliminary clin- 
ical results of Descemet membrane endothelial keratoplasty. Am J Ophthalmol 2008;145:222-7. [CrossRef]

14. Price MO, Price Jr FW. Endothelial keratoplasty-a review. Clin Experiment Ophthalmol 2010;38:128-40. [CrossRef]

15. Terry MA. Endothelial keratoplasty: why aren't we all doing Descemet membrane endothelial keratoplasty?. Cornea 2012;31:469-71.

16. Eye Bank Association of America. 2015 eye banking statistical report. Available at: http://restoresight.org/wp-content/uploads/2016/03/2015-Statistical-Report.pdf. Accessed Feb 15, 2021.

17. Chaurasia S, Price FW, Gunderson L, Price MO. Descemet's membrane endothelial keratoplasty: clinical results of single versus triple procedures (combined with cataract surgery). Ophthalmology 2014;121:454-8. [CrossRef]

18. Padmanabhan P, Warade SK, Sejpal K. New endothelial keratoplasty, phacoemulsification, and intraocular lens implantation triple procedure: comparison with conventional triple procedure. J Cataract Refract Surg 2010;36:1142-8. [CrossRef]

19. Ham L, Dapena I, Moutsouris K, Balachandran C, Frank LE, Van Dijk K, et al. Refractive change and stability after Descemet membrane endothelial keratoplasty: effect of corneal dehydration-induced hyperopic shift on intraocular lens power calculation. J Cataract Refract Surg 2011;37:1455-64. [CrossRef]

20. Schoenberg ED, Price FW, Miller J, McKee Y, Price MO. Refractive outcomes of Descemet membrane endothelial keratoplasty triple procedures (combined with cataract surgery). J Cataract Refract Surg
2015;41:1182-9. [CrossRef]

21. Alnawaiseh M, Rosentreter A, Eter N, Zumhagen L. Changes in corneal refractive power for patients with Fuchs endothelial dystrophy after DMEK. Cornea 2016;35:1073-7. [CrossRef]

22. Ham L, Van Luijk C, Dapena I, Wong TH, Birbal R, Van der Wees J, et al. Endothelial cell density after Descemet membrane endothelial keratoplasty: 1-to 2-year follow-up. Am J Ophthalmol 2009;148:521-7. [CrossRef]

23. Cirkovic A, Schlötzer-Schrehardt U, Weller JM, Kruse FE, Tourtas T. Clinical and ultrastructural characteristics of graft failure in DMEK: 1-year results after repeat DMEK. Cornea 2015;34:11-7.

24. Dapena I, Ham L, Droutsas K, van Dijk K, Moutsouris K, Melles GR. Learning curve in Descemet's membrane endothelial keratoplasty: first series of 135 consecutive cases. Ophthalmology 2011;118:2147-54. [CrossRef]

25. Ham L, Van Der Wees J, Melles GR. Causes of primary donor failure in Descemet membrane endothelial keratoplasty. Am J Ophthalmol 2008;145:639-44. [CrossRef]

26. Maier P, Reinhard T, Cursiefen C. Descemet stripping endothelial keratoplasty-rapid recovery of visual acuity. Dtsch Ärztebl Int 2013;110:365-71. [CrossRef]

27. Maier AK, Wolf T, Gundlach E, Klamann MK, Gonnermann J, Bertelmann E, et al. Intraocular pressure elevation and post-DMEK glaucoma following Descemet membrane endothelial keratoplasty. Graefes Arch Clin Exp Ophthalmol 2014;252:1947-54. [CrossRef]

\section{Katarakt Cerrahisi ve Göz içi Lensi Uygulaması İle Kombine Yapılan Descemet Membran Endotelyal Keratoplasti}

Amaç: Katarakt ile birlikte kornea endotel disfonksiyonu olan olgularda fakoemülsifikasyon ve göz içi lensi uygulaması ile kombine yapılan descemet membran endotelyal keratoplasti cerrahisinin (Triple DMEK) görsel anatomik sonuçlarının ve komplikasyonların değerlendirilmesi.

Gereç ve Yöntem: Ocak 2014-Temmuz 2018 tarihleri arasında Kartal Dr. Lütfi Kırdar Eğitim ve Araştırma Hastanesi Göz Hastalıkları Kliniği'nde Triple DMEK cerrahisi yapılan 32 hastanın 39 gözü geriye dönük olarak değerlendirmeye alındı. Olguların ameliyat öncesi ve sonrası I., 3., 6. ve I2. aydaki düzeltilmiş en iyi görme keskinlikleri (DEIGK), endotel hücre sayısı (EHS), santral korneal kalınlığı (SKK), ortalama refraktif sferik eşdeğerleri (SE), tekrar hava verilme (THV) sıklı̆ı ve komplikasyonları değerlendirildi.

Bulgular: DEIGK ameliyat öncesi $1.22 \pm 0.32 \log M A R$ iken $(n=39)$, ameliyat sonrası 6 . ayda $0.19 \pm 0.18(n=33)$, 12 . ay sonunda $0.11 \pm 0.09$ $(n=27) \log M A R ' a$ yükselmiştir $\left(p<0.05\right.$; Wilcoxon test). EHS donör korneada $277 I \pm 284$ hücre $/ \mathrm{mm}^{2}(n=39)$ iken, ameliyat sonrası 6 . ayda $|40| \pm 270$ hücre $/ \mathrm{mm}^{2}(n=32)$, I2. ay sonunda $1373 \pm 217$ hücre/mm²'ye $(n=24)$ düşmüştür $(p<0.05)$. SKK ameliyat öncesi $696 \pm 99 \mu$ m'dan, ameliyat sonrası altıncı ayda $518 \pm 42 \mu \mathrm{m}, 12$. ay sonunda $517 \pm 35 \mu$ m'a düşmüştür $(p<0.05)$. Ortalama refraktif SE ameliyat öncesi $-0.57 \pm 0.69$ $D$ iken $(n=21)$, altıncı ayda $+0.47 \pm 0.65 D(n=31)$, 12. ay sonunda $0.48 \pm 0.67 D(n=27)$ olarak ölçüldü. On ikinci ayda hastaların \%82'sinde ortalama sferik eşdeğer I D veya altında saptandı. Çalışmamızda 7 göze I kez (\% I7.9), 2 göze ise 2 kez (\%5.I2) THV işlemi yapıldı. Greft yetmezliği gelişen 7 gözün 6'sına tekrar DMEK, I göze ise penetran keratoplasti yapıldı.

Sonuç: Triple DMEK cerrahisinin, düşük red reaksiyonu riski, öngörülebilir refraktif sonuçları, kapalı sistem cerrahisinin avantajları ve korneal sütür komplikasyonlarının ihmal edilebilir düzeyde düşük olması, düşük doz steroid tedavisinin yeterli olması nedeniyle kornea endotel disfonksiyonu ile birlikte kataraktı olan olgularda tedavi seçenekleri arasında ilk sıralarda olduğunu düşünüyoruz.

Anahtar Sözcükler: Fuchs'un endotel distrofisi; kombine modalite tedavisi; kornea nakli. 